\title{
Pneumoperitoneum: a rare air leak in an infant with bronchiolitis and high-frequency oscillatory ventilation
}

\author{
Ramnik V Patel, ${ }^{1,2}$ Hemant Kumar, ${ }^{3}$ Nitin Patwardhan, ${ }^{3}$ Brice Antao ${ }^{4}$
}

${ }^{1}$ Department of Paediatric Urology, University College London Hospitals NHS Foundation Trust, London, UK ${ }^{2}$ Department of Paediatric Urology, Great Ormond Street Children Hospital NHS Trust, London, UK

${ }^{3}$ Department of Paediatric Surgery, LRI, Leicester, UK ${ }^{4}$ Department of Paediatric Surgery, Our Lady's Children's Hospital, Dublin, UK

Correspondence to Ramnik V Patel,

ramnik@doctors.org.uk

\footnotetext{
To cite: Patel RV, Kumar $\mathrm{H}$, Patwardhan $\mathrm{N}$, et al. BMJ Case Rep Published online: [please include Day Month Yearl doi:10.1136/bcr-2013010447
}

\section{DESCRIPTION}

A 4-month-old male infant developed respiratory distress, respiratory synchitial virus bronchiolitis with bilateral segmental collapse consolidation of upper zones requiring intraosseous vascular access with left tibial fracture, intubation and difficult mechanical ventilation. He was being treated in paediatric intensive care unit for the past 10 days and required antibiotics, dexamethasone, ribavirin, nitric oxide and high frequency oscillatory ventilation. He then developed abdominal distention, but was tolerating feeds and passing normal stools. His abdomen was soft, non-tender, bowel sounds were normal and all laboratory investigations including inflammatory markers were within normal limits. X-ray abdomen demonstrated pneumoperitoneum (figure 1A). Chest X-ray taken previous day showed right lower zone pneumothorax with a clear rim of pneumomediastinum around heart (figure 1B) and the chest X-ray of the same day revealed flattened hemidiaphragm, shift of mediastinum to the left with pneumomediastinum and pneumoperitoneum (figure 1C). He was treated for the chest infection, but simply observed for pneumoperitoneum clinically and finally recovered well (figure 1D). $\mathrm{He}$ is asymptomatic and thriving well at 2-year follow-up.

Pneumoperitoneum in an infant is almost always interpreted as an evidence of rupture of a hollow viscus such as gastrointestinal perforation. ${ }^{1-3}$ Emergency exploratory laparotomy is generally required in such cases involving bowel perforation. ${ }^{2}$ Asymptomatic radiologically recognised pneumoperitoneum still remains a diagnostic and therapeutic dilemma, because free intraperitoneal air is not necessarily caused by alimentary tract perforation. Infants with acute respiratory distress and the need for mechanical ventilation may develop pneumoperitoneum in the case of an air leak syndrome. One must keep in mind the possibility of this

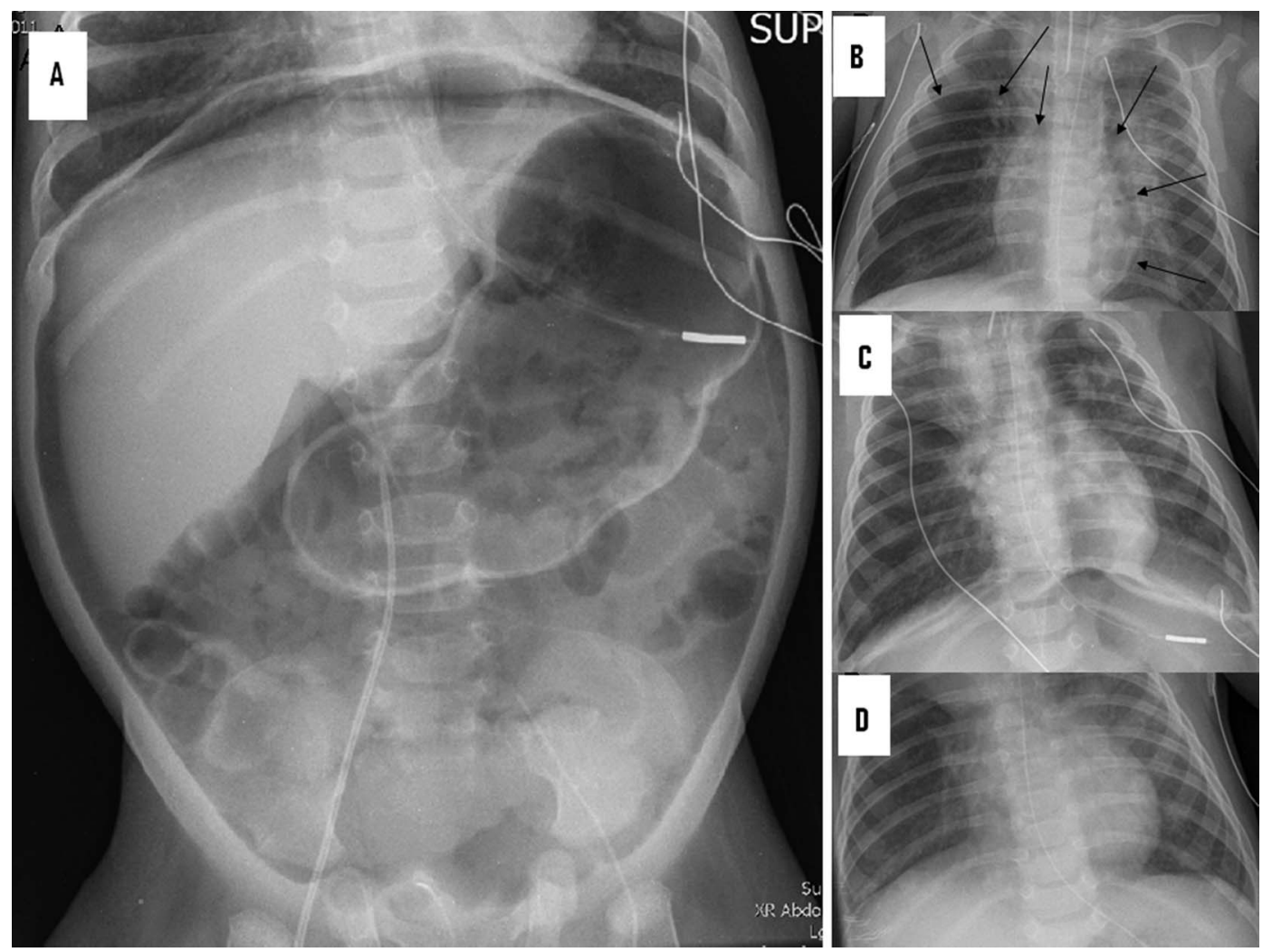

Figure 1 Abdominal and chest $X$-ray. (A) Note massive pneumoperitoneum with well-preserved gastrointestinal bowel gas pattern and gas on both sides of the bowel wall. (B-D) Chest X-ray before, during and after pneumoperitoneum showing right lower zone segmental pneumothorax and clear rim of pneumomediastinum around heart (B), pneumoperitoneum (C) and postrecovery (D). 
benign condition and refrain from any interventions including needle aspiration if the patient is stable.

\section{Learning points}

Even if in most cases of massive pneumoperitoneum, the standard treatment is surgical exploration; keeping in mind this rare condition could be useful.

- Nonetheless, high-frequency oscillatory ventilation (HFOV) is thought to reduce air leaks in infants with mechanical ventilation. Therefore, the case per se is interesting, because it demonstrates that pneumoperitoneum can also be induced by HFOV.

- Avoid unnecessary operation in the case of 'benign' non-surgical pneumoperitoneum.
Contributors All authors have been involved in the active clinical management of this patient and have taken part in collection, analysis and interpretation of the data and in writing, revising and submitting the manuscript.

Competing interests None.

Patient consent Obtained.

Provenance and peer review Not commissioned; externally peer reviewed.

\section{REFERENCES}

1 D'Agostino S, Fabbro MA, Musi L, et al. Pneumatosis cystoides intestinalis: a rare cause of nonsurgical pneumoperitoneum in an infant. J Pediatr Surg 2000;35:1106-8

2 Zarella JT, McGullough JY. Pneumoperitoneum in infants without gastrointestinal perforation. Surgery 1982;89:163-7.

3 Brown DR, Keenan WI. Pneumoperitoneum without gastrointestinal perforation in neonate. J Paediatr 1974;85:377-9.

Copyright 2013 BMJ Publishing Group. All rights reserved. For permission to reuse any of this content visit http://group.bmj.com/group/rights-licensing/permissions.

BMJ Case Report Fellows may re-use this article for personal use and teaching without any further permission.

Become a Fellow of BMJ Case Reports today and you can:

- Submit as many cases as you like

- Enjoy fast sympathetic peer review and rapid publication of accepted articles

- Access all the published articles

- Re-use any of the published material for personal use and teaching without further permission

For information on Institutional Fellowships contact consortiasales@bmjgroup.com

Visit casereports.bmj.com for more articles like this and to become a Fellow 